\title{
Přinesla „Pospíšilova“ reforma kárného řízení skutečně zpřísnění kárného postihu českých soudců?*
}

\section{Has "Pospíšil's" Reform of Disciplining Judges Really Led to Harsher Disciplinary Sanctions?}

\author{
David Kosař ${ }^{* *}$, Tereza Papoušková ${ }^{* * *}$
}

\begin{abstract}
Abstrakt
Cilem tohoto článku je posoudit dìsledky zavedeni nového modelu kárného rízeni se soudci prosazenou ministrem spravedlnosti Jirrm Pospišilem v roce 2008. „Pospišilova reforma“ (zákon č. 314/2008 Sb.) prènesla kárné ř̌zeni na Nejyyšš správni soud, zavedla jednoinstančni kárné rǐzeni se soudci, zakotvila smišené složeni kárných senáti s paritním zastoupenim soudci a nesoudcu a v mnoha obledech zprǒsnila kárné rǐzení (napr. zvýšnim sankcí, prodloužením subjektivnich i objektivnich lbưt pro podáni kárné žaloby a zakotvenim institutu ,trìkrát a dost!"). Na české pomèry se jednalo o revolučni żmènu. Nebylo tedy prekevapením, že soudci

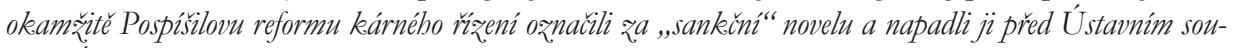

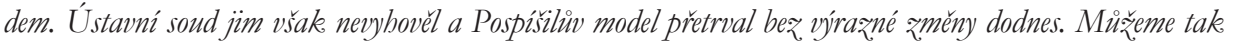

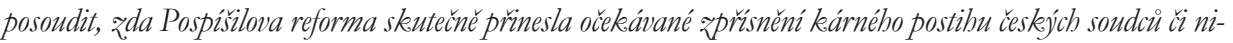
koliv. Za timto úcelem tento clánek porovnává výsledky kárných ř̌zeni se soudci zabájených pred Pospísilovou reformou v letech 2003-2008 s vísledky kárných ř́zeni se soudci zahájených po Pospišilovè reformé v letech 2009-2014. Hlavním závèrem naši kvantitativni studie je, že v rozporu s očekáváním tviorcu Pospišilovy reformy, ke zprǔsnèni kárného postibu českéch soudcu ve strédnèdobém horizontu v drtivé vétsinè ukazateli nedošlo. Po implementaci Pospišilově reformy totižpoklesl počet kárných návrbü, nominálně i percentuálně poklesl poúet kárných návrhiu, v nichž bylo uloženo kárné opatrení, poklesl počet soudcu ,donucených k odložení taláru" "tj. součet soudci odvolaných z funkce soudce kárným soudem a soudcü, ježn na funkci soudce rezignovali v pribèbu kárnébo rǐzení) a poklesla i celková úspěšnost kárných navrbovatelu.
\end{abstract}

\section{Klíčová slova}

Soudy; soudci; kárné rěrení; nezávislost soudcu; justični reforma.

\section{Abstract}

The aim of this article is to assess consequences of the introduction of a new model of disciplining judges proposed by the Minister of Justice Jiri Pospisil and his allies in 2008. The so-called "Pospisil's reform" (Law no. 314/2008 Coll.) transferred disciplinary trials with judges to the Supreme Administrative

\footnotetext{
* Výzkum, který vedl k výsledkům publikovaným v tomto článku, získal finanční prostředky od Grantové agentury ČR (projekt č. 13-07384P, panel č. P408).

** Doc. JUDr. David Kosař, Ph.D., LL.M., J. S. D., Ústav pro otázky soudnictví, Právnická fakulta, Masarykova univerzita, Brno / Judicial Studies Institute, Faculty of Law, Masaryk University, Brno, Czech Republic / E-mail: David.Kosar@law.muni.cz / ORCID: orcid.org/0000-0001-5025-1367

*** Mgr. et Mgr. Tereza Papoušková, Ústav pro otázky soudnictví a Katedra ústavního práva a politologie, Právnická fakulta Masarykovy univerzity, Brno / Judicial Studies Institute and Department of Constitutional Law and Political Science, Faculty of Law, Masaryk University, Brno, Czech Republic / E-mail: tereza.papouskova@law.muni.cz
} 
Court, introduced single-instance disciplinary proceedings with judges, established mixed composition of disciplinary panels with a parity of judges and non-judges, and in many aspects tightened disciplinary proceedings (e.g. by allowing harsher sanctions, extending subjective as well as objective time limits for initiating the disciplinary motion, and establishing the "three strikes" principle). In the Czech context it was a revolutionary change. Not surprisingly, judges immediately challenged Pospisili's reform before the Czech Constitutional Court (CCC). However, the CCC rejected their arguments and thus Pospisisil's model has prevailed until today. That allows us to ask the following research question: Has Pospisill's reform met the expectations of the drafters and led to harsher disciplinary sanctions of Czech judges? To answer this question we employ the "before/after" research design and compare the results of disciplinary motions with judges initiated before Pospisil's reform (between 2003 and 2008) with the results of disciplinary motions initiated after Pospisil's reform (between 2009 and 2014). The main conclusion of our quantitative study is that, contrary to the expectations of the drafters, Pospisil's reform has not (regarding almost all indicators) tightened disciplining of Czech judges in the medium term. Most importantly, after the implementation of Pospisil's reform the number of disciplinary motions declined, the number of successful disciplinary motions (i.e. the motions that led to a disciplinary punishment) decreased nominally as well as proportionally, and the number of judges who were forced to leave the judiciary (i.e. the total number of judges who were either recalled by a disciplinary panel or resigned after the disciplinary motion had been initiated against them) dropped as well.

\section{Keywords}

Courts; Judges; Disciplinary Proceedings; Independence of Judges; Judicial Reform.

\section{Úvod}

Když v roce 2008 tehdejší ministr spravedlnosti Jiří Pospíšil předložil ${ }^{1}$ svou reformu kárného řízení se soudci, ${ }^{2}$ vyvolalo to mezi soudci obrovské pozdvižení. ${ }^{3}$ Kritika této reformy nabrala ještě více na síle poté, co ji hladce schválil parlament České republiky. ${ }^{4}$ Není se čemu divit. Pospíšilova reforma zásadně změnila institucionální nastavení českého kárného soudnictví, nebot' přenesla tuto agendu z vrchních soudů a Nejvyššího soudu na Nejvyšší správní soud (dále též „NSS“), zavedla jednoinstanční kárné rúizení, zakotvila paritní složení „soudcovských“55 kárných senátů, které se nově skládají ze tří soudců a třî

1 Vláda předložila návrh zákona Poslanecké sněmovně dne 20. února 2008, nicméně Jiří Pospíšil př́ipravoval svou reformu pochopitelně déle - první verze věcného záměru změn byla dokončena Ministerstvem spravedlnosti již v lednu 2007.

2 Srov. zákon č. 314/2008 Sb., kterým se mění zákon č. 6/2002 Sb., o soudech, soudcích, přísedících a státní správě soudů a o změně některých dalších zákonů (zákon o soudech a soudcích), ve znění pozdějších předpisů, zákon č. 150/2002 Sb., soudní řád správní, ve znění pozdějších préedpisů, zákon č. 7/2002 Sb., o řízení ve věcech soudců a státních zástupců, ve znění pozdějších předpisů, zákon č. 349/1999 Sb., o Veřejném ochránci práv, ve znění pozdějších předpisů, zákon č. 283/1993 Sb., o státním zastupitelství, ve znění pozdějších předpisů, zákon č. 200/1990 Sb., o přestupcích, ve znění pozdějších předpisů, a zákon č. 85/1996 Sb., o advokacii, ve znění pozdějších předpisů (dále jen „zákon č. 314/2008 Sb.“, „Pospíšilova novela“ či „Pospíšilova reforma“); a důvodovou zprávu k tomuto zákonu.

3 Srov. např̀ ŠIMKA, Karel. Návrh novely zákona o soudech a soudcích a zákona o řízení ve věcech soudců a státních zástupců. Právní roz̧hledy, 2007, roč. 15, č. 12, s. 2.

4 Pospíšilova novela byla schválena 16. července 2008 a vstoupila v účinnost 1. řijna 2008.

5 Zde upozorňujeme na skutečnost, že složení kárných senátů při NSS pro státní zástupce (jež bylo rovněž pozměněno Pospíšilovou novelou) je odlišné: soudce NSS, soudce Nejvyššího soudu, 2 státní zástupci, advokát a zástupce právnických fakult. 
nesoudců, ${ }^{6}$ a v mnoha ohledech zpřísnila kárné ř́zení (např. zvýšením sankcí, prodloužením subjektivních i objektivních lhůt pro podání kárné žaloby a zakotvením institutu „třikrát a dost!" ). Navíc samo ministerstvo spravedlnosti si v části Pospíšilovy novely týkající se kárného soudnictví vytyčilo za cíl „zprúísnění kárného řízení“?

Soudci Pospíšilovu novelu zákona o soudech a soudcích a zákona o řízení ve věcech soudců a státních zástupců označili za „,sankční novelu“8 a okamžitě napadli klíčový aspekt Pospíšilovy novely, tj. jednoinstančnost kárného řízení, u Ústavního soudu. ${ }^{9}$ Ústavní soud však návrhu nevyhověl a zamítl jej, přičemž „posvětil“ i paritní složení kárných senátů. ${ }^{10}$ Pospíśilův model kárného soudnictví tak ,přežil“" ústavní přezkum ${ }^{11}$ a přetrval bez větších změn až dodnes.

Okamžitě se rovněž vyrojily spekulace o tom, co vlastně Pospíšilova reforma přinese. Jeden tábor kritiků této reformy očekával zpřísnění kárného postihu českých soudců. Podle jiných komentátorů nový model kárných řízení sloužil ministru Pospíšilovi jen „k získání levných populistických bodư“ v rámci tažení proti „falešné soudcovské kolegialitě“, a tudíž žádné výrazné změny nepřinesl. ${ }^{12}$ Podobně rozpornou interpretaci dopadů Pospíšilovy reformy poskytovaly i první zevrubné analýzy rozhodování nových kárných senátů. Například Jaromír Jirsa v roce 2011 poukazoval na to, že nové kárné senáty ještě neodvolaly žádného soudce z funkce a tvrdil, že rozhodují podobně jako dosud, a tudíž k žádnému zpř́isnění nedošlo. ${ }^{13}$ Svůj článek Jirsa dokonce ukončil ironickou úvahou, aby náhodou „ministr spravedlnosti za pár let nevolal po znovuobnovení starého, čistě soudcovského modelu a aby sami soudci nebojovali za laický prvek“. ${ }^{*}$

6 V některých případech jsou nesoudcovští členové kárných senátů označováni za „laiky“. Označovat státního zástupce či advokáta, který má obdobnou profesní zkoušku a léta praxe ve stejném systému jako soudce (respektive profesora právnické fakulty), za „laika“, tedy rétoricky jej stavět na stejnou úroveň jako skutečně laické „přísedíci““ (u nichž se nevyžaduje právnické vzdělánî), nepovažujeme za přiléhavé.

7 Srov. blíže část 2.1.

8 K vnímání Pospíšilovy reformy jako „,sankčni““ novely srov. KOSAŘ, David. Reflexe fungování kárného soudnictví v České republice. In: ČAPUTOVÁ, Zuzana a Eva KOVÁČECHOVÁ (eds.). Vybrané aspek.ty disciplinárníbo súdnictva. Pezinok: Via Iuris, 2013, s. 13-16.

9 Přesněji řečeno, návrh na zrušení klíčových ustanovení Pospíšilovy novely Ústavnímu soudu předložil kárný senát NSS v řízení o konkrétní kontrole norem.

10 Srov. nález Ústavního soudu sp. zn. Pl. Ús 33/09 ze dne 29. 9. 2010.

11 Jisté pochybnosti o vhodnosti i ústavnosti Pospíšilovy reformy kárného soudnictví však přetrvávají i po nálezu Ústavního soudu; srov. nesouhlasná stanoviska připojená k nálezu Ústavního soudu sp. zn. Pl. ÚS 33/09 ze dne 29. 9. 2010; KOHOUTEK, Milan. Z jednání kolegia předsedů krajský soudů. Soudce, 2011, roč. 13., č. 3, s. 4; MALENOVSKÝ, Radek. Několik úvah nad vhodností a ústavností určitých aspektů kárného řízení se soudci. Právní roz̧hledy, 2011, roč. 19, č. 11, s. 402-408; ZEMANOVÁ, Daniela. Rozhodování kárných senátů Nejvyššího správního soudu ve věcech soudců za období řijen 2008 srpen 2012: Objektivní statistika a subjektivní pohled předsedkyně kárného senátu. In: ČAPUTOVÁ, Zuzana a Eva KOVÁČECHOVÁ (eds.). Vybrané aspekty disciplinárního súdnictva. Pezinok: Via Iuris, 2013, s. 9; nebo KOSǍ̌, David, Marek ANTOŠ, Zdeněk KÜHN a Ladislav VYHNÁNEK. Ústavní právo: Casebook. Praha: Wolters Kluwer, 2015, s. 248-256.

12 Srov. JIRSA, Jaromír. Soudcovská nezávislost a kárné řízení. Soudce, 2011, roč. 16, č. 8, s. 8-13.

13 Tamtéž.

14 Tamtéž. Tento názor, že nové kárné senáty mohou být (zejména vzhledem k př́itomnosti nesoudců, kteří mohou mít větší úctu vůči soudcům a nemusejí dohlédnout dalekosáhlost důsledků jejich pochybenî) ve skutečnosti ještě mírnější, ostatně neveřejně zastávalo nemálo znalců českého justičního prostředí. 
Na tento článek reagoval Tomáš Němeček, který s Jirsou nesouhlasil a konstatoval, že nová kárná řízení skutečně „,přinesla reálné zpřísnění, které je však na první pohled „neviditelné“, a proto si ho málokdo uvědomuje. ${ }^{15}$ Tato „,neviditelnost“ podle Němečka spočívala v tom, že pro posouzení dopadů Pospíšilovy reformy je nutné vzít v potaz nejen meritorní rozhodnutí kárných senátů, ale i zastavení kárného řízení z důvodu vzdání se funkce kárně stíhaným soudcem, které může být motivované hrozbou z príisné sankce kárného senátu. Nejednoznačné intepretace poskytovaly i pozdější úvahy o kárných řízeních se soudci po Pospíšilově reformě. Např́iklad Daniela Zemanová v roce 2012 uvedla, že si žádnou analýzu sice nedělala, ale nepřekvapilo by ji, kdyby „,supersenáty“ rozhodovaly tak jako předtím kárné senáty na vrchních soudech. ${ }^{16}$

Vzhledem k tomu, že od účinnosti Pospíšilovy reformy uplynulo již více než 8 let, je možné tyto prvotní úvahy ověrit a zhodnotit střednědobé ${ }^{17}$ důsledky nového modelu kárného soudnictví. Hlavní výzkumná otázka tohoto článku zní tedy následovně: Přinesla Pospíšilova reforma ve střednědobé perspektivě očekávané zpř́isnění kárného postihu českých soudců či nikoliv? Za účelem zodpovězení této otázky tento článek porovnává výsledky ukončených ${ }^{18}$ kárných řízení se soudci zahájených préd Pospíšilovou reformou v letech 2003-2008 s výsledky kárných řízení se soudci zahájených po Pospíšilově reformě v letech 2009-2014, tj. v období šest let před účinností novely a v období šest let po ní. ${ }^{19}$

Vzhledem k omezenému rozsahu si tento článek neklade za cíl komplexní kvalitativní posouzení ${ }^{20}$ dopadů Pospíšilovy novely. Jeho cílem je posoudit její dopady na kárné rúzení

15 Srov. NĚMEČEK, Tomáš. Zločin a pokárání: Po prohře se soudcem Kozákem ministerstvo spravedlnosti uvažuje o změně pravidel pro kárné ř́zení. Lidové noviny, 23. 1. 2012, s. 17.

16 Srov. parafrázi výroků Daniely Zemanové. Tamtéž, s. 17.

17 Tento článek si neklade za cíl predikovat dloubodobé důsledky Pospíšilovy reformy.

18 Z tohoto do̊vodu se nevěnujeme kárným řízením zahájeným v pozdějších letech, nebot' řada z nich nebyla ještě ukončena meritorním rozhodnutím, což by zásadním zpưsobem ovlivňovalo interpretaci „nekompletních“ dat v letech 2015-2017. Členění na roky 2003-2008 a 2009-2014 navíc umožňuje porovnat dva modely kárného řízení - Burešův (který nabyl účinnosti 1. dubna 2002) a Pospíšilův (který nabyl účinnosti 1. října 2008). Pokud bychom chtěli zkoumat výsledky kárných řízení před rokem 2003, museli bychom zohlednit existenci odlišného „federálního“ modelu kárného soudnictví (fungujícího v letech 1993-2002).

19 Přesněji řečeno, je pro nás v následujících analýzách rozhodující datum 1. 10. 2008 (účinnost Pospíšilovy novely), rrízení jsou tedy dělena na řízení zahájená v období 1. 1. 2003 - 30. 9. 2008 a v období 1. 10. $2008-31.12 .2014$.

20 K tomu srov. např. MALENOVSKÝ, 2011, op. cit. (viz pozn. č. 11); BOBEK, Michal. Odpovědnost a disciplína soudce (v přerodu?). Právní roz̧hledy, 2011, roč. 19, č. 14, s. 502-510; MATES, Pavel a Karel ŠEMÍK. Nad důstojností soudcovského stavu. Jurisprudence, 2014, roč. 23, č. 2, s. 40-45; FRIEDEL, Tomáš. Jak čeští soudci (ne)smí jednat: Praxe kárného soudu ve věcech kárných řízení se soudci v letech 2008-2014. Jurisprudence, 2015, roč. 24, č. 1, s. 15-23; či HAUPTFLEISCHOVÁ, Iva. Chování a jednání soudce „mimo talár“ jako kárné provinění z pohledu samotných soudců. Časopis pro právni védu a praxi, 2015, roč. 23, č. 3, s. 290-301. 
se soudci ${ }^{21}$ toliko z hlediska základních kvantitativních kritérií. Samotný článek se skládá z následujících částí. Část 1 shrnuje nejdůležitější změny, které Pospíšilova reforma kárného řízení přinesla, a rovněž se krátce zamýšlí nad vyřčenou i nevyřčenou motivací, jež za ní stála. Část 2 tvoří jádro článku a skrze analýzu konečných rozhodnutí vydaných v kárných řízeních v obdobích zhruba šest let před účinností Pospíšilovy novely (2003-2008) a šest let po ní (2009-2014) zkoumá z kvantitativního hlediska dopady Pospíšilovy reformy českého kárného soudnictví. Část 3 interpretuje výstupy z části 2 a ukotvuje je do širšího kontextu. Č́st 4 shrnuje závěry tohoto článku.

\section{Shrnutí Pospíšilovy reformy kárného řízení a toho, co $\mathrm{k}$ ní vedlo}

Tato část ve zkratce rozebere hlavní změny, které Pospíšilova novela přinesla, a nastíní atmosféru v době přijímání této novely, která nám umožní lépe pochopit motivaci pro reformu českého kárného soudnictví. Oba aspekty, jak skutečný rozsah Pospíšilovy reformy, tak vyřčené i nevyřčené důvody, jsou klíčové pro kontextualizaci kvantitativních výstupů naší analýzy kárných řízení se soudci v letech 2003-2014.

\section{1 „Revolučni'“ aspekty Pospíšilovy reformy kárného řízení}

Před Pospíśilovou novelou bylo kárné řízení se soudci dvojinstanční - v první instanci rozhodovaly vrchní soudy, proti jejichž rozhodnutí mohli kárně stíhaní soudci podat odvolání k Nejvyššímu soudu. ${ }^{22} \mathrm{Na}$ obou stupních rozhodovali o kárných proviněních soudců senáty složené výhradně ze soudců z povolání. Tento „Burešův model“ kárného soudnictví zakotvený v roce 2002 z institucionálního hlediska úzce navazoval na „federální model“ kárného soudnictví, ${ }^{23}$ který na území České republiky fungoval s drobnými změnami ${ }^{24}$ od roku 1991 do prìjetí nového zákona o soudech a soudcích ${ }^{25}$ a nového kárného řádu ${ }^{26}$ prosazených tehdejším ministrem spravedlnosti Jaroslavem Burešem. ${ }^{27}$

21 V této souvislosti je nutné zmínit, že Pospíšilova reforma se vztahovala i na kárná řizení se státními zástupci. K tomu srov. VRBÍK, Marek. Rozhodovací praxe Nejvyššího správního soudu, jakožto kárného soudu, v řízeních o kárné odpovědnosti státních zástupců. Státní zastupitelstuí, 2015, roč. 13, č. 2, s. 29-37; MOTYČKA, Petr. Kárná řízení advokátů, soudců a státních zástupců anebo měří se všem stejným metrem? Bulletin advokacie, 2015, roč. 45, č. 1-2, s. 46-52; LATA, Jan. Vývoj kárného řízení ve věcech státních zástupců. Státní zastupitelství, 2015, roč. 13, č. 4, s. 16; a FRIEDEL, Tomáš. Ještě o kárném řízení advokátů, soudců a státních zástupců. Bulletin advokacie, 2015, roč. 45, č. 10, s. 49-52. K praxi později vytvořených kárných senátů ve věcech soukromých exekutorů, srov. VYLEGALA, Jan. Jednoinstančnost či dvojinstančnost kárného řízení ve věcech soudních exekutorů? Casopis pro právní védu a praxi, 2013, roč. 21, č. 1, s. 94-100.

22 Srov. \3 odst. 2 ve spojení s $\int 21$ zákona č. $7 / 2002$ Sb., o řízení ve věcech soudců a státních zástupců ve znění před novelou č. 314/2008 Sb.

23 Zákon č. 412/1991 Sb., o kárné odpovědnosti soudců.

24 Pro podrobnější rozbor vývoje právní úpravy kárné odpovědnosti soudců na území České republiky srov. BOBEK, 2011, op. cit. (viz pozn. č. 20).

25 Zákon č. 6/2002 Sb., o soudech, soudcích, přísedících a státní správě soudů a o změně některých dalších zákonů (zákon o soudech a soudcích).

26 Zákon č. 7/2002 Sb., o řízení ve věcech soudců a státních zástupců.

27 Proto tento model označujeme pro lepší odlišení od „Pospíšilova modelu“ jako „Burešův model“. 
Pospíšilova reforma vnesla do kárného soudnictví hned několik zásadních změn. V prvé řadě přenesla kárná řízení se soudci z vrchních soudů a Nejvyššího soudu na NSS, který se nově stal jediným kárným soudem. ${ }^{28}$ Dále zavedla ve věcech kárného řízení se soudci jednoinstanční kárné rúzení, čímž znemožnila kárné stíhaným soudcưm podat proti rozhodnutí nových kárných senátů odvolání. ${ }^{29} \mathrm{~V}$ nových kárných senátech při NSS navíc nezasedají pouze soudci z povolání a dokonce nemají ani většinu. Pospíšilova novela totiž zakotvila šestičlenné kárné senáty s paritně zastoupeným soudcovským a nesoudcovským prvkem z odborné právní veřejnosti. Nové kárné senáty se skládají ze tří soudců a tř́ nesoudců, a to konkrétně z jednoho soudce NSS (který je zároveň předsedou senátu), jednoho soudce Nejvyššího soudu, jednoho soudce nižších soudů, jednoho státního zástupce, jednoho advokáta a jedné osoby vykonávající jiné právnické povolání, což je zpravidla člen akademického sboru jedné z českých právnických fakult. ${ }^{30}$

Kromě těchto institucionálních změn Pospíšilova novela v mnoha ohledech zpř́snila samotné kárné řízení. Konkrétně zvýšila horní hranici sankce snížení platu a prodloužila dobu jejího působení, ${ }^{31}$ prodloužila subjektivní i objektivní lhůty pro podání kárné žaloby $^{32}$ a zakotvila institut „trrikrát a dost!“" pro zahájení ŕízení o nezpưsobilosti k výkonu funkce soudce $\mathrm{v}$ důsledku třetího pravomocného odsouzení pro kárný delikt v předchozích pěti letech. ${ }^{33}$

$\mathrm{Na}$ české poměry šlo tedy o rozsáhlé změny, byt’ řada z nich nebyla tak revoluční, jak je soudcovský stav podával. ${ }^{34}$ Co k těmto změnám ale přesně ministra spravedlnosti Jiř́iho Pospíšila vedlo? Na to se pokusí najít odpověd’ následující část tohoto článku.

\subsection{Proč k této novele vůbec došlo?}

Prvotním vodítkem pro zjištění motivace Jiřího Pospíšila a jeho týmu je důvodová zpráva k zákonu č. 314/2008 Sb. V obecné rovině důvodová zpráva konstatuje, že změny úpravy kárného řízení by měly přispět $\mathrm{k}$,zefektivnění práce justice“. ${ }^{35}$ Pokud jde o nesoudcovské členy kárných senátu, přísedící z řad jiných právních profesí by podle záměrů tvůrců reformy ,mèli do kárnébo rízeni vnést úbly pobledu odlišné od těch, které lzue predpokládat

28 Srov. \ 3 kárného řádu ve znění po novele č. 314/2008 Sb.

29 Srov. \ 21 kárného řádu ve znění po novele č. 314/2008 Sb.

30 Srov. \ 4 a \ 5 kárného řádu ve znění po novele č. 314/2008 Sb.

31 Srov. \8 88 odst. 1 a 2 zákona o soudech a soudcích.

32 Srov. \ 9 odst. 1 kárného řádu ve znění po novele č. 314/2008 Sb.

33 Srov. \91 písm. c) zákona o soudech a soudcích.

34 Např. jednoinstanční kárné řízení existovalo pro soudce (alespoň některých soudů) podle rakouskouherské úpravy účinné do roku 1950, podle komunistických kárných řádů (srov. \ 19 zákona č. 67/1950 Sb.; a \ 5 a 15 zákona č. 37/1957 Sb.) i podle federálního modelu kárného soudnictví (srov. \5 a 18 zákona č. 412/1991 Sb. ve znění do 31. 12. 1992 a \ 5 a 18 zákona č. 412/1991 Sb. ve znění po 31. 12. 1992) přetrvávajícího až do Burešovy reformy v roce 2002.

35 Důvodová zpráva k zákonu č. 314/2008 Sb., sněmovní tisk, č. tisku: 425/0. 
u členư kárných senátů žrad soudcư, a mèli by umožnit posoudit kárnéprovinèni komplexnèji a objektivněji ‘. ${ }^{36}$ Jinak řečeno, cílem navrhované úpravy bylo zvýšit objektivitu při rozhodování kárných soudů o kárných proviněních soudců ,a odstranit tak v co nejvyšš́ míre vz̨nik možných pochybností o nestrannosti rozhodováni v tèchto stavovských vécech“. ${ }^{37}$ Pokud jde o druhou zásadní změnu, zavedení jednoinstančního kárného řízení, důvodová zpráva se opírá o rozsáhlou historickou a komparativní analýzu, ale pro pochopení skutečné motivace tvưrců Pospíšilovy novely je důležitější pasáž, v níž je implicitně kritizována rozhodovací praxe Nejvyššího soudu v kárných věcech. Ministerstvo spravedlnosti totiž zastávalo závěr, že „druhostupňový soud v podobě kárného senátu Nejvy šš́ho soudu v praxi funguje jako jakýsi orgán „graciačni", který nepochybuje o skutkových zjižstènich prvnostupñovébo kárného soudu, tradičně však pouze uložené kárné opatreni żmírni ${ }^{*}{ }^{38}$ tj. sníží srážky z platu či úplně upustí od potrestání. Tolik k zásadním institucionálním změnám.

Ohledně hmotněprávních úprav kárné odpovědnosti je důvodová zpráva rovněž zdrženlivá a skutečnou motivaci otevřeně neuvádí. Zvýšení maximální hranice kárného opatření snížení platu soudce je odůvodněno potřebou „rožšrinit] prostor pro úvahu senátu kárného soudu o tom, jaké kárné opatrení má v projednávané věci uložit "39 prodlužení subjektivní a objektivní lhůty pro zahájení kárného řízení „by mèlo poskytnout vètši časový prostor pro posouzeni skutku, keterý je nebo by mobl být kárným provinèním“40 a zakotvení zásady „třikrát a dost“" navrhovatel považuje za nezbytné proto, aby „každý takový konkéétní prǐpad [opakovaného kárného proviněni] mobl posoudit nezávislý soud, který roz̧hodne o tom, zda uvedená situace zpochybñuje divvéryhodnost dalšího setrváni soudce v soudcovské funkeci" ${ }^{41}$

Důvodová zpráva tak „zpř́isnění“ kárného postihu českých soudců výslovně jako svou motivaci nezmiňuje. Šlo tedy jen o přehnanou reakci soudcovského stavu? Ne tak docela. Skutečnou motivaci Pospíšilovy reformy odhalil jeho náměstek František Korbel, který rok po nabytí účinnosti Pospíšilovy novely konstatoval, že „[c]ílem [reformy kárného řízeni] bylo dosáhnout jistébo zpřísnění a navráceni divvěryhodnosti kárného systému v oǔch verejnosti, nebot’ tento byl téžce pošramocen nèkolika exemplárnimi př́klady stavov ské solidarity mezi soudci a nedìsledností či zjevnè nepriměrenou mirnosti některých kárných rozsudkü, zejména Nejvyššího soudu. Zvlásté flagrantní byl prǒpad mladoboleslavského soudce Pavla Nagyho, který byl za „vymyšleni" celého

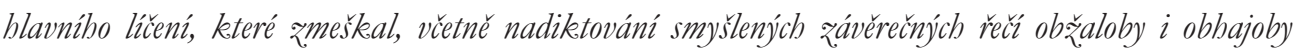
a vyneseni rozsudku ,potrestán" Nejvyššim soudem sniženim platu o jednu čtvrtinu na pül roku“. ${ }^{42}$

\footnotetext{
36 Důvodová zpráva k zákonu č. 314/2008 Sb., sněmovní tisk, č. tisku: 425/0.

37 Tamtéž (dưraz doplněn).

38 Tamtéž.

39 Tamtéž.

40 Tamtéž.

41 Tamtéž.

42 KORBEL, František. „Ministerská“ novela zákona o soudech a soudcích. ASPI, 2009, ASPI ID: LIT34568CZ (důraz doplněn).
} 
Tuto motivaci potvrzuje i Daniela Zemanová, která v rozhovoru s Tomášem Němečkem uvedla, že „,[n] ikedo to nikedy výslovně nerekel, ale podle mého názoru celá novela vžnikla kvvili jednomu odvolacímu senátu na Nejyyššim soudu, s nimž nikedo neumèl nic udělat " ${ }^{43}$ Podle Tomáše Němečka tím Daniela Zemanová naráží právě na senát Nejvyššího soudu, jemuž předsedal Jiří Pácal - podle Němečka ,jeho senát vrátil talár i proslulému lhári Pavlu Nagyovi, který

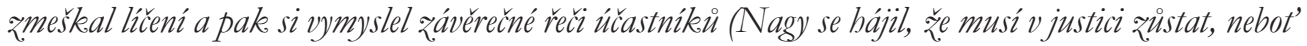
by se „tě̌̌̌ko adaptoval na jinou práci)“" 44

Z toho jasně plyne, že hlavní motivací Pospísillovy reformy byla skutečně snaha o zpřísnění kárného postihu českých soudců, príčemž jako záminka pro tento krok posloužilo několik excesů jednoho senátu Nejvyššího soudu. Zpř́snění kárného postihu českých soudců však nebylo cílem samo o sobě - mělo sloužit vyššímu cilli, a to konkrétně zvýšení legitimity celého kárného procesu navenek a v konečném důsledku zvýšení důvěry veřejnosti v soudnictví. ${ }^{45}$

\section{Kárná řízení se soudci před Pospíšilovou novelou (2003-2008) a po ní (2009-2014)}

Dopady Pospíšilovy reformy jsme zjišt'ovali skrze analýzu konečných rozhodnutí vydaných v kárných řízeních v obdobích zhruba ${ }^{46}$ šest let před účinností novely a šest let po ní. ${ }^{47}$ Samotná kvantitativní analýza těchto rozhodnutí pochopitelně nemůže postihnout veškeré myslitelné dopady Pospíšilovy novely, nicméně přináší zajímavé a relevantní výsledky, na kterých se dá následně stavět. ${ }^{48}$

Prvním hlediskem, které se k posouzení dopadů novely přirozeně nabízí, ovšem z nějž lze tyto posuzovat jen ve velice omezené míře, je počet návrhů na zahájení kárného řízení. Jak naznačuje Graf č. 1, v letech 2009 až 2014 bylo návrhů na zahájení kárného řízení se soudci podáno o něco méně než v letech předchozích. ${ }^{49}$ Konkrétněji, před Pospíšilovou novelou bylo průměrně podáno asi 33 návrhů na zahájení kárného řízení proti soudci ročně, kdežto po novele jich k NSS ročně napadlo jen asi $28,{ }^{50}$ což představuje pokles

43 Srov. citaci Daniely Zemanové in NĚMEČEK, 2012, op. cit. (viz pozn. č. 15).

44 Srov. NĚMEČEK, 2012, op. cit. (viz pozn. č. 15).

45 K rozboru těchto vyšších cílů srov. zejména BOBEK, 2011, op. cit. (viz pozn. č. 20).

46 Slovo „zhruba“ zde odkazuje na skutečnost, že novela nabyla účinnosti ke konci roku 2008, konkrétně 1. 10.2008.

47 Rozhodnutí vydaná v řízeních zahájených po Pospíšilově novele jsme stáhli z webu NSS. Rozhodnutí vydaná v rrízeních zahájených dříve jsme získali od Ministerstva spravedlnosti.

$48 \mathrm{~V}$ této souvislosti poukazujeme rovněž na skutečnost, že v tomto článku z důvodu omezeného prostoru nezohledňujeme mírně kolísající celkový počet soudců obecných soudů v České republice ve sledovaných letech 2003-2014. Tohoto zjednodušení jsme si vědomi, nicméně v letech 2003-2014 byl český soudcovský stav již naplněn a rozdíly v počtu soudců v tomto období jsou zanedbatelné. Srov. KOSAŘ, David. Perils of Judicial Self-Government. Cambridge: Cambridge University Press, 2016, s. 216 a Annex C.

49 Respektive, přesněji, v těchto letech bylo zahájeno méně kárných řízení (nesledovali jsme datum podání návrhu, ale datum zahájení řízení).

50 Z výpočtu ročních průměrů počtu návrhů kárných řízení zahájených před novelou a po ní byl vynechán rok 2008, protože 3 z celkových 39 návrhů podaných v tomto roce byly již vyřizovány v novém režimu. Navíc se lze domnívat, že počet řízení zahájených v tomto roce (at' už před účinností novely nebo po nî) mohl být připravovanou změnou ovlivněn. 
přibližně o $15 \%$. Jak jsme však již předeslali, nelze samozřejmě tvrdit, že po novele byli oprávnění navrhovatelé stran podání návrhů na zahájení kárných řízení proti soudcům zdráhavější (a tedy že soudcům kárné provinění častěji procházelo) nebo naopak že soudci v letech po novele více dodržovali své povinnosti a méně narušovali důstojnost soudcovské funkce nebo ohrožovali důvěru v soudnictví. Takové závěry by totiž bylo možno činit až po zohlednění všech př́padů, v nichž navrhovatelé mohli/měli zvažovat podání návrhů na zahájení kárného řízení proti soudcům, a motivů, které je vedly k rozhodnutí návrh (ne)podat. Znalost jen těch případů, kdy se navrhovatelé nakonec rozhodli návrh skutečně podat, k učinění takových závěrů nepostačuje. Jelikož je ovšem počet návrhů podaných před novelou a po ní a počet návrhů podaných v jednotlivých letech nestejný, budeme v následujících analýzách pracovat s relativními, a nikoliv absolutními hodnotami. ${ }^{51}$

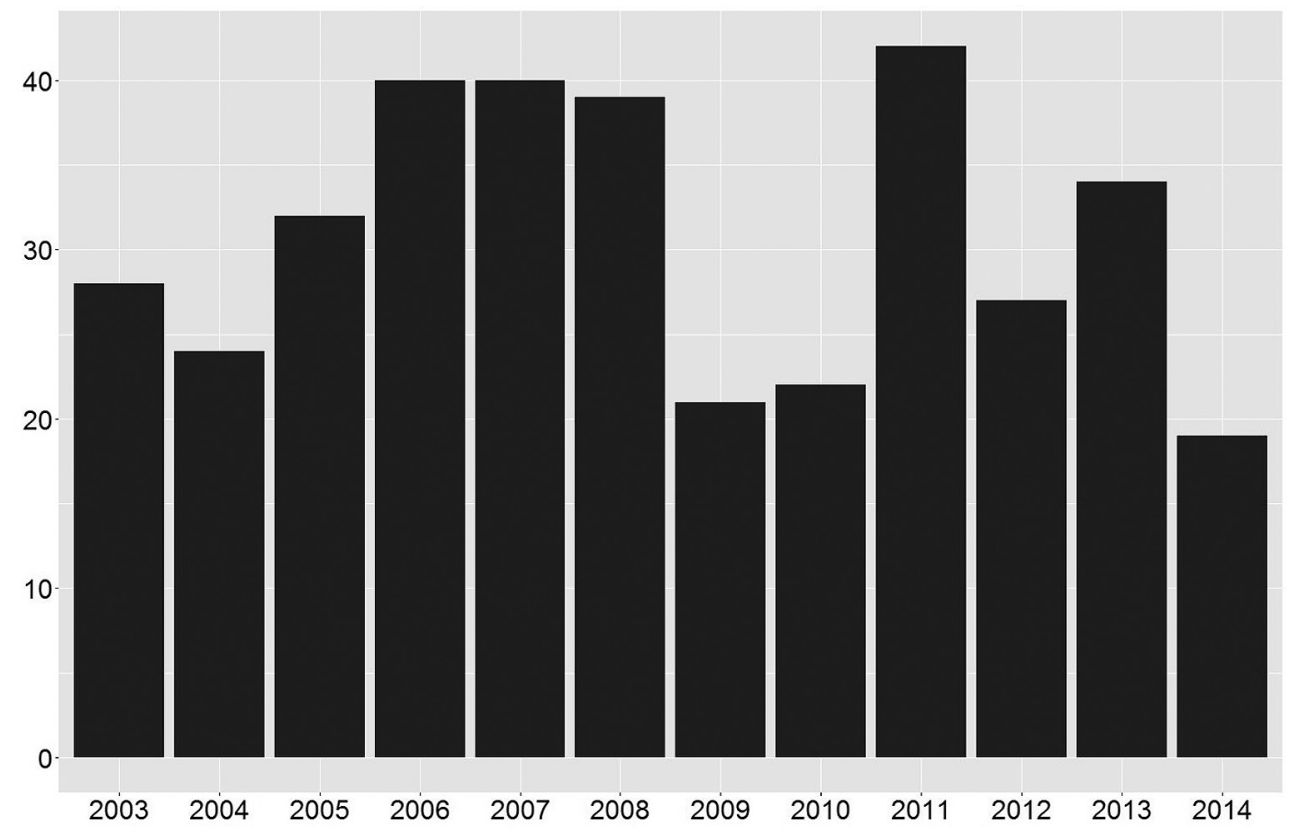

Graf č. 1: Počet kárných řízení zahájených v jednotlivých letech

Další hlediska, na jejichž základě je možné dopad Pospíšilovy novely posuzovat, je možné rozdělit do dvou větších skupin. První skupinu tvoří hlediska vyplývající z kárných návrhů samotných, druhou pak hlediska vyplývající až z konečného rozhodnutí kárného soudu. Do první skupiny tak spadají převažující typ navrhovatele, převažující článek soudní soustavy, v rámci nějž působili kárně stíhaní soudci, a převažující typ jejich

51 Pro úplnost je nutno uvést, že z dalších analýz vynecháváme 2 ze 168 návrhů kárných řízení zahájených po novele, nebot' o nich nemáme požadované informace (konkrétně jde o řízení vedená pod sp. zn. 11 Kss 9/2011 a 11 Kss 6/2012). 
kárného provinění. Do druhé pak výsledek kárných řízení, úspěšnost jednotlivých typů navrhovatelů a povaha uložených kárných opatření. Samožrejmě existuje i mnoho dalších, námi na základě prosté kvantitativní analýzy rozhodnutí vydaných v kárných řízeních nepostižených hledisek. Těmi mohou být jak již výše zmiňovaná autokorekce nežádoucího jednání ze strany soudců zapř́ičiněná strachem z prŕśných postihů nebo proměna uvažování potenciálních navrhovatelů, tak např́klad i změna ve způsobu argumentace navrhovatelů nebo odůvodnění rozhodnutí kárného soudu. Jak jsme však již upozorňovali, tento článek si neklade za cíl komplexní kvalitativní posouzení dopadů Pospíšilovy novely. Jeho cílem je posoudit její dopady z hlediska základních kvantitativních kritérií.

Začneme první ze dvou výše zmiňovaných skupin, tedy údaji vypovídajícími o kárných návrzích samotných. Co se týče prvního z nich - typu navrhovatele - sledovali jsme, jakou část (podíl) kárných řízení v daném roce (Graf č. 2) a v období před novelou a po ní (Graf č. 3) zahájil předseda téhož soudu, kde působil kárně stíhaný soudce, či předseda soudu nadř́zeného a jak aktivní byli z tohoto pohledu ministr spravedlnosti a ostatní aktivně legitimovaní navrhovatelé. ${ }^{52}$ Jak ze srovnání např́č jednotlivými roky, tak i z celkového porovnání stavu před novelou a po ní je patrné, že po Pospíšilově novele mírně vzrostl podíl návrhů podaných ministrem spravedlnosti. Nejviditelnější je tento nárůst v roce 2011, kdy ministr spravedlnosti zahájil 15 z celkových 41 kárných rúzení (asi $37 \%$ ), přičemž předsedové týchž soudů se na celkovém počtu návrhů podíleli asi z $59 \%$ (24 ze 41 kárných návrhů) a zbylých $5 \%$ návrhů (2 kárné návrhy) podali předsedové soudů nadřízených. ${ }^{53}$ Za povšimnutí nicméně stojí, že téměř polovina (konkrétně sedm) řízení zahájených na návrh ministra spravedlnosti v roce 2011 byla vedena proti soudcům Okresního soudu v Děčíně, a to proto, že tito soudci měli rozhodnout o povolení zjišt’ování údajů o telekomunikačním provozu na podkladě nedostatečně odůvodněné žádosti policejního orgánu. Přitom ani jedno z těchto řízení nevyústilo v uložení kárného opatření, ani v dobrovolnou rezignaci stíhaného soudce. Nelze tedy patrně hovořit o tom, že by ministr spravedlnosti byl ve srovnání s ostatními typy navrhovatelů v období po Pospíšilově novele výrazně aktivnější, tedy že by novela měla, co se týče míry aktivity jednotlivých typů navrhovatelů ve srovnání s ostatními navrhovateli, nějaký významný dopad.

52 Těmi byli v období před novelou zejména Policie ČR a v období po novele pak Veřejný ochránce práv a prezident České republiky.

53 Pro srovnání, předsedové týchž soudů se na celkovém počtu řízení zahájených v daném roce nejvíce podíleli v roce 2004, tedy v období před Pospíšilovou novelou, kdy na jejich návrh bylo zahájeno $92 \%$ všech řízení ( 22 z 24). Celkově spíše zdrženliví předsedové soudů nadřízených podali návrh na zahájení největší části řízení naopak po novele, a to v roce 2009, kdy na jejich návrh bylo zahájeno 19 \% řízení (4 z 21). 

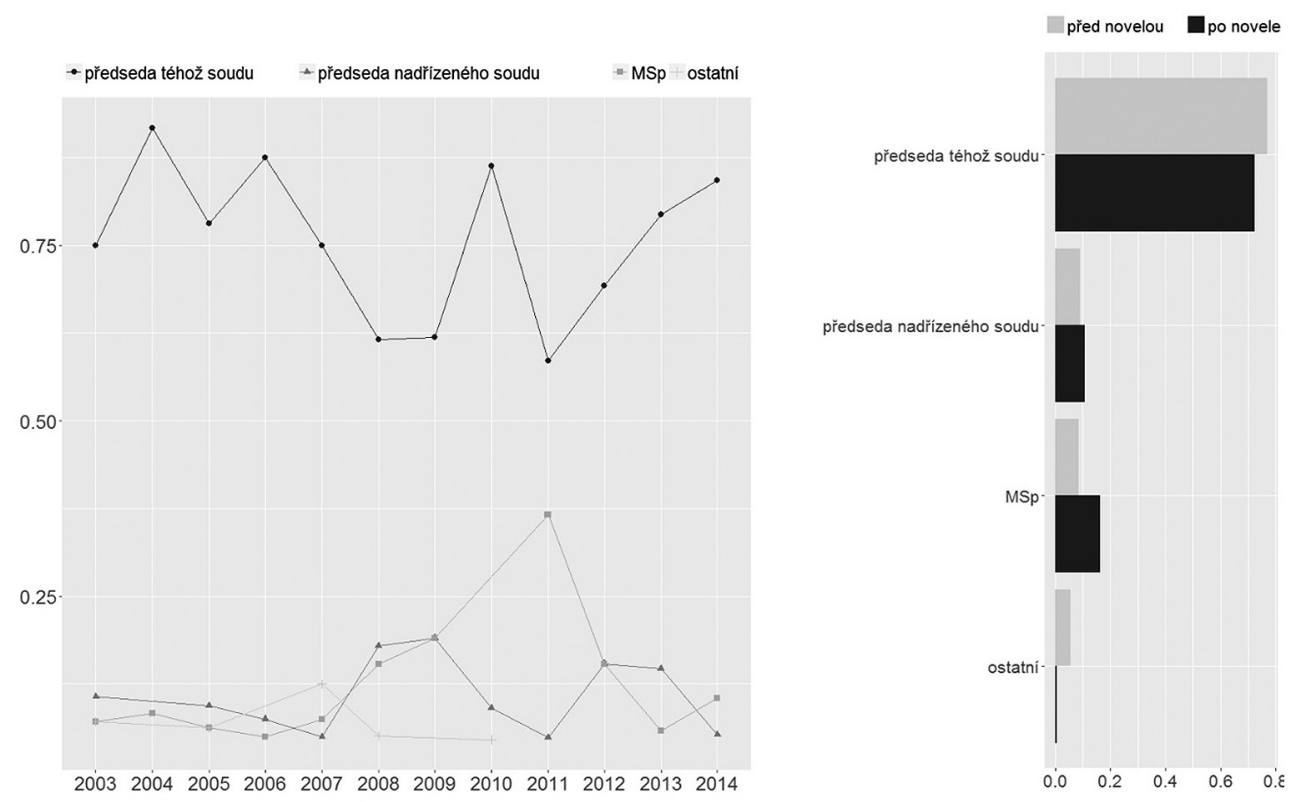

Grafy č. 2 a 3: Podíl návrhů na zahájení kárného řízení podaných různými typy navrhovatelů v celkovém počtu návrhů podaných $\mathrm{v}$ jednotlivých letech a v období před novelou a po ní

V rámci první skupiny hledisek posuzování dopadů Pospíšilovy novely jsme se dále zaměřili na údaj o soudu, na němž působil kárně stíhaný soudce, respektive jsme jej (pro nedostupnost původního údaje pro návrhy podané před novelou) transformovali toliko na údaj o článku soudní soustavy. Opět jsme sledovali podíl návrhů kárných řízení podaných proti soudcům okresních/krajských/vrchních/nejvyšších zahájených v jednotlivých letech a celkově v období před novelou a po ní. Tentokrát nicméně ani prvotní pohled na meziroční srovnání, ani pohled na celkové srovnání období před novelou a po ní nenaznačovaly přítomnost nějakého významnějšího trendu. ${ }^{54}$ Za povšimnutí tak stojí snad jen skutečnost, že zatímco v období před novelou byla zahájena čtyři kárná řízení proti soudcům nejvyšších soudů, v období po novele nebylo proti těmto soudcům zahájeno řízení žádné. Naopak proti soudcům vrchních soudů byla zahajována řízení spíše po novele (trri z celkových čtyř kárných řízenî).

$\mathrm{O}$ výraznější změně v období po novele ve srovnání s obdobím před ní lze hovořit u třetího z námi sledovaných hledisek první skupiny, a to u typu kárných provinění, za které byli soudci stíháni. Jak vyplývá z meziročního srovnání podílů řízení vedených proti soudcům pro jednotlivé námi definované typy kárných provinění na celkovém počtu řízení zahájených v daném roce (Graf č. 4) i ze srovnání těchto podílů v obdobích před novelou a po ní (Graf č. 5), soudci jsou jednoznačně nejčastěji kárně stíhaní pro neodůvodněné průtahy $\mathrm{v}$ rrízeních. Ovšem zatímco z řízení zahájených před účinností

$54 \mathrm{Z}$ důvodu omezeného prostoru $\mathrm{v}$ tomto článku zde tyto grafy neuvádíme (tyto grafy jsou k dispozici na vyžádání u autorů článku). 
Pospíšilovy novely bylo 66 \% (131 z 200) proti soudcům vedeno právě z důvodu průtahů, po novele tento podíl klesl na $54 \%$ (80 ze $\left.148^{55}\right)$. Naproti tomu z 9 na asi $20 \%$ po novele vzrostl podíl řízení vedených proti soudcům pro kárná provinění spočívající v chování nebo jednání, jímž měl soudce narušovat důstojnost soudcovské funkce nebo ohrožovat důvěru v nezávislé, nestranné, odborné a spravedlivé rozhodování soudů. $\mathrm{V}$ meziročním srovnání $\mathrm{v}$ tomto směru opět (stejně jako $\mathrm{v}$ př́padě analýzy převažujícího typu navrhovatelů) významně vystupuje rok 2011, kdy bylo pro kárné provinění, námi kódované jako „rozpor se soudcovskou nezávislostí a etikou“, vedeno 14 z 34 kárných řízení (tedy asi $41 \%$ ). V úvahu je nicméně opět třeba vzít oněch sedm řízení zahájených na návrh ministra spravedlnosti v tomto roce proti soudcům Okresního soudu v Děčíně, nebot' všechna byla vedena právě pro kárné provinění daného typu. I roky 2012 a 2013 ovšem byly z hlediska vysokého podílu kárných řízení vedených proti soudcům právě pro podezření z kárného provinění spočivajícího v porušení principů soudcovské nezávislosti a etiky a zároveň nízkého podílu soudců stíhaných pro průtahy poměrně význačné. Již jen pro zajímavost pak uved'me, že soudce, který byl stíhán pro průtahy v nejvíce věcech, se jich prokazatelně dopustil ve 447 řízeních. Za toto kárné provinění bylo této soudkyni uloženo $20 \%$ snížení platu na dobu jednoho roku. ${ }^{56}$
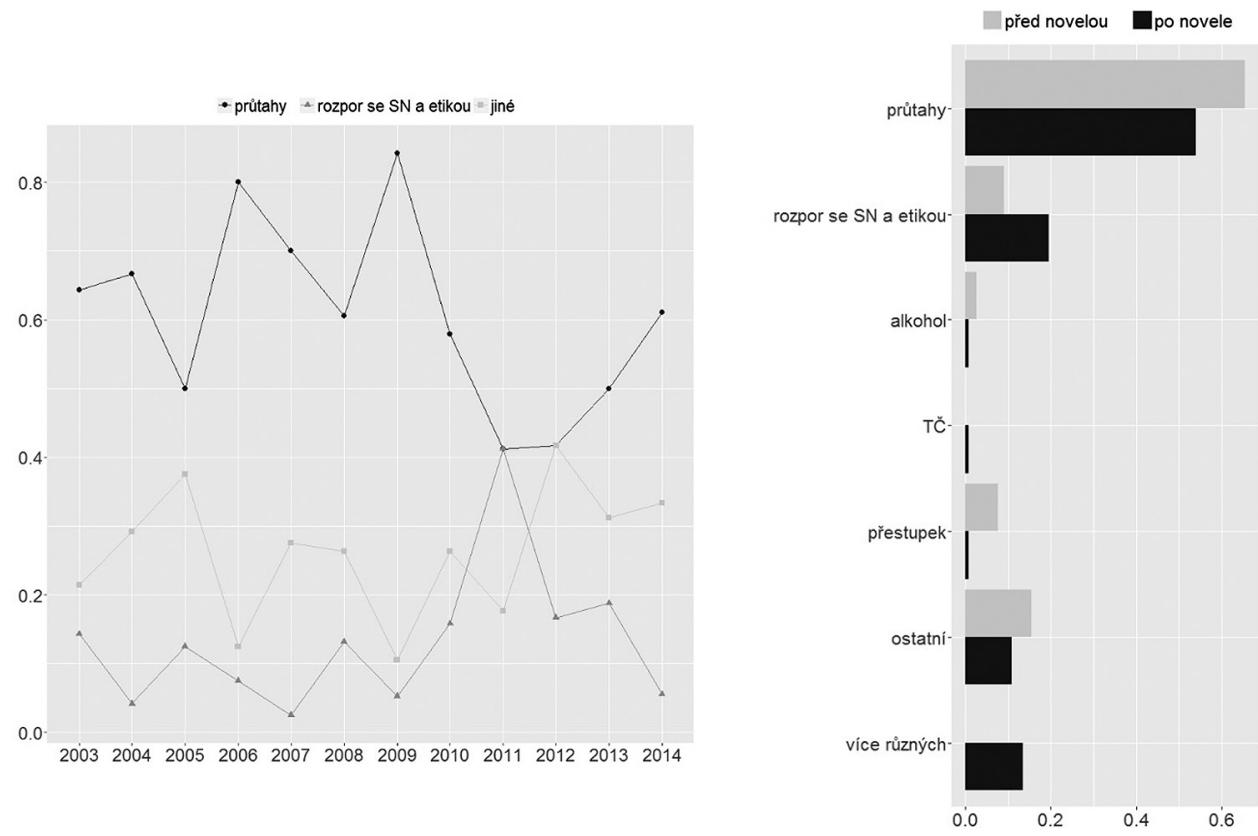

Grafy č. 4 a 5: Podíl kárných řízení vedených proti soudcům pro různé typy kárných provinění v celkovém počtu rrízení zahájených v jednotlivých letech a v období před novelou a po ní

55 Zde je nutno upozornit, že u 20 řízení zahájených po novele není údaj o povaze kárného provinění, pro nějž byl daný soudce stíhán, znám.

56 Rozhodnutí kárného senátu NSS ze dne 29. 5. 2013 sp. zn. 11 Kss 4/2013. 
Přesuňme se nyní k druhé skupině hledisek srovnávání období před Pospíšilovou novelou a po ní, tedy $\mathrm{k}$ hlediskům vyplývajícím z rozhodnutí vydaných v kárných řízeních. Prvním z nich je podíl jednotlivých typů výsledků řizení. V této kategorii jsme konkrétně sledovali, jaká část řízení zahájených v daném roce (Graf č. 6) či v období před novelou a po ní (Graf č. 7) vyústila v to, že se kárně stíhaný soudce vzdal své funkce, v jaké části řízení bylo kárně stíhanému soudci uloženo kárné opatření a jaká část řízení skončila jinak, tj. napřriklad upuštěním od uložení kárného opatření soudci, který se kárného provinění dopustil, úplným zproštěním viny, zpětvzetím návrhu na zahájení řízení ${ }^{57}$ či zastavením řízení. ${ }^{58}$ Již na první pohled je zřejmé, že po novele byla kárná opatření ukládána v menší míre než před ní, zatímco tento pokles nebyl zcela dorovnán množstvím př́padů, v nichž se kárně stíhaní soudci (snad) v obavě z kárného postihu vzdali své funkce. ${ }^{59}$ Konkrétněji, z 200 rrízení zahájených v období před novelou vyústilo 120 řízení $(60$ \%) v uložení kárného opatření stíhanému soudci a 21 (asi 11 \%) ve vzdání se funkce soudce, kdežto ze 166 kárných ř́zení zahájených po novele byla kárná opatření uložena v 66 řízeních (asi $40 \%$ ), přičemž 22 soudců (asi $13 \%$ ) se vzdalo funkce. V této souvislosti je však vhodné upozornit na skutečnost, že v posledním sledovaném roce, v roce 2014, byl podíl kárných řízení, která vyústila v uložení kárného opatření, již srovnatelný s podílem těchto řízení v letech před novelou, zatímco podíl kárných řízení, která vyústila v to, že se kárně stíhaný soudce vzdal funkce, byl na celkovém minimu.

Pokud sečteme počet řízení, v nichž bylo uloženo kárné opatření, a počet řízení, v jejichž průběhu se kárně stíhaný soudce vzdal funkce, zjistíme celkovou úspěšnost kárných navrhovatelů. V období prèed novelou kární navrhovatelé uspěli ve 141 rrízeních z 200 (70,5\%), zatímco po novele „jen“ v 88 ř́zeních ze 166 (zhruba 53 \%). Pro doplnění jsme sledovali i úspěšnost jednotlivých typů navrhovatelů, tj. podíl na jejich návrh zahájených řízení, která vyústila bud' v uložení kárného opatření stíhanému soudci, nebo v to, že se vzdal své funkce. Z výsledků srovnání úspěšnosti jednotlivých typů navrhovatelů v období před novelou a po ní ${ }^{60}$ je zřejmé, že pokles v „přísnosti“ kárných řízení se projevil ve všech řízeních bez ohledu na to, na čí návrh byla zahájena.

$57 \mathrm{~K}$ tomu docházelo především z dưvodu polepšení kárně stíhaného soudce. Zajímavé však může být, že v jednom př́ípadě došlo ke zpětvzetí návrhu proto, že se dle navrhovatele, ministra spravedlnosti, podobného pochybení jako kárně stíhaný soudce (přeměny trestu obecně prospěšných prací na trest odnětí svobody v nesprávné délce) systematicky dopouští i řada dalších soudců (viz rozhodnutí kárného senátu NSS ze dne 22. 3. 2012 sp. zn. 16 Kss 1/2012).

$58 \mathrm{~K}$ zastavení řízení docházelo především proto, že byly návrhy na zahájení daných kárných řízení podány opožděně, nebo například z důvodu úmrtí kárně stíhaného soudce. Kárné řízení proti dvěma soudcům pak bylo zastaveno $z$ důvodu zániku jejich funkce $\mathrm{v}$ důsledku odsouzení v trestním řízení. Pro úplnost ještě uved'me, že jako ,jiný“ výsledek kárného řízení označujeme případy, kdy byla věc postoupena či kdy bylo rozhodováno o povolení obnovy řízení či v řízení obnoveném.

59 Srov. NĚMEČEK, 2012, op. cit. (viz pozn. č. 15).

$60 \mathrm{Z}$ důvodu omezeného prostoru $\mathrm{v}$ tomto článku zde tento graf neuvádíme (tento graf je $\mathrm{k}$ dispozici na vyžádání u autorů článku). 

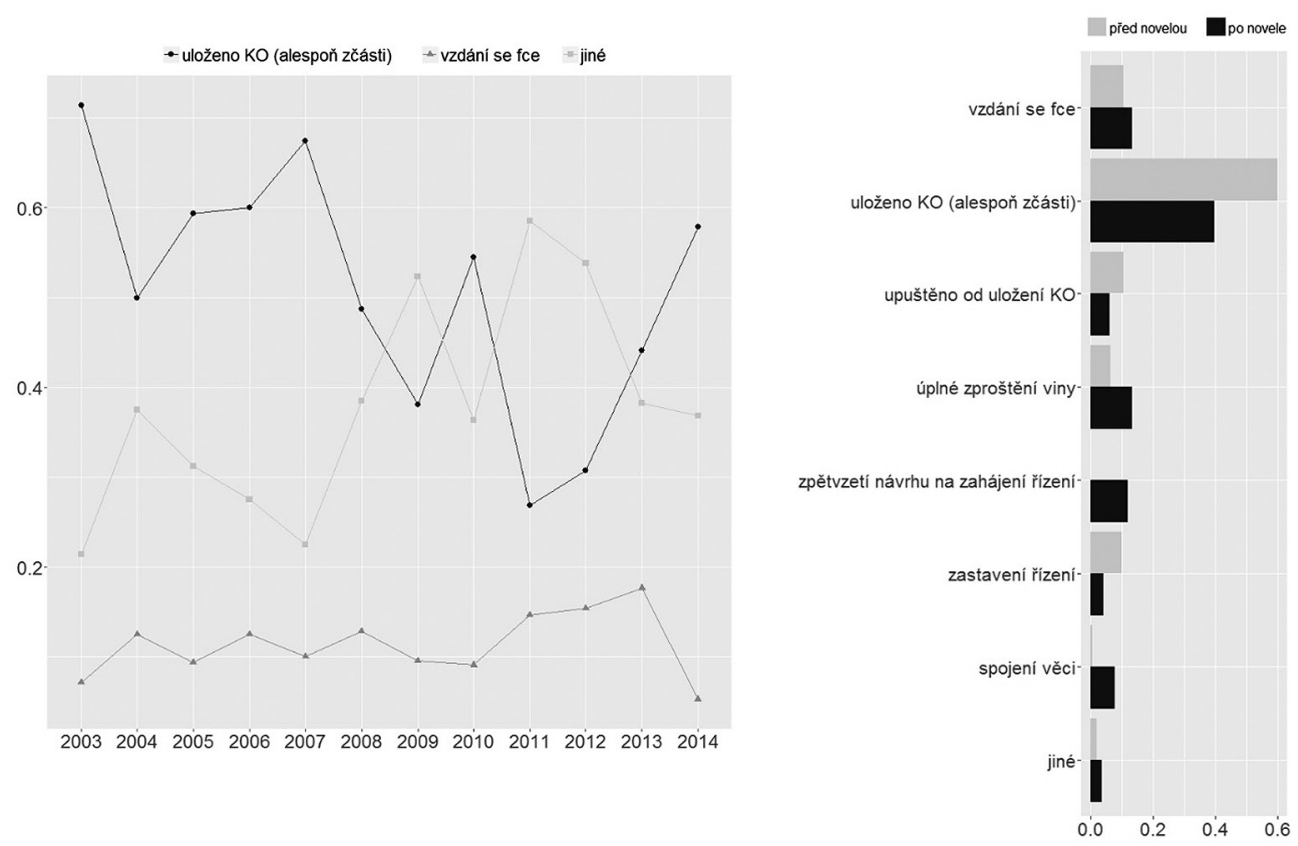

Grafy č. 6 a 7: Podíl kárných řízení s různými výsledky v celkovém počtu řízení zahájených $\mathrm{v}$ jednotlivých letech a v období před novelou a po ní

Víme-li nyní, že v rízeních zahájených v období po novele byla ukládána kárná opatření $\mathrm{v}$ menší míře, zaměřme se na povahu těchto kárných opatření. Ze srovnání podílu jednotlivých typů uložených kárných opatření na všech kárných opatřeních uložených v rízeních zahájených v daném roce (Graf č. 8) a v období před novelou a po ní (Graf č. 9) je patrné, že nejčastěji je soudcům snižován plat. ${ }^{61}$ Podíl tohoto kárného opatření v období po novele mírně vzrostl (z 58 na $70 \%$ ), zatímco v tomto období mírně klesl podíl př́ípadů, kdy byl kárně stíhaný soudce odvolán z funkce (z 8 na $5 \%$ ) či kdy mu byla uložena důtka (z 29 na $26 \%$ ). Za povšimnutí také stojí skutečnost, že kárné opatření ve formě snižení platu uložené v řízeních zahájených po novele bylo navíc vưči jednotlivým soudcům $\mathrm{v}$ průměru více než dvakrát př́snější. Konkrétněji, vztáhneme-li kárné opatření ve formě snížení platu $\mathrm{k}$ jednomu měsíčnímu platu soudce, $\mathrm{v}$ období před novelou bylo v průměru na jedno řízení ukládáno snížení platu asi o $67 \%$, ovšem v období po novele již asi o $153 \%$. Jinak řečeno, před novelou soudce, kterému bylo uloženo kárné opatření spočívající ve snížení platu, „př̌išel“ průměrně jen o dvě třetiny svého měsíčního platu, zatímco po novele již soudce, jemuž bylo uděleno stejné kárné opatření, „prrišel“" o jeden a půl svého měsíčního platu.

61 Pro zajímavost, nejčastěji (v 16 ze 114 př́ípadů, ve kterých došlo k uložení tohoto kárného opatřenî) byl soudcům snížen plat právě o $10 \%$ na dobu 3 měsíců. 
Co se týče kárného opatření ve formě odvolání soudce z funkce, může být zajímavé, že v ř́izeních zahájených v období před novelou bylo toto opatření uloženo devíti soudcům, z nichž dva byli opilí na pracovišti, šest se dopustilo průtahů a jeden jednal v rozporu se soudcovskou nezávislostí a etikou. V období po novele pak byli z funkce odvoláni tři soudci, a to $z$ důvodu průtahů, $v$ jednom př́padě doplněných o neoprávněnou manipulaci s elektronickým soudním spisem. Celkově lze tedy říci, že v období před novelou bylo donuceno opustit soudcovský stav 30 soudců (výše zmíněných devět soudců bylo k tomuto kroku donuceno kárným opatřením, zatímco 21 soudců se vzdalo funkce soudce po zahájení kárného řízenî) a v období po novele pak došlo k zániku funkce v souvislosti s kárným řízením u 25 soudců ( $z$ toho tři soudci byli k tomuto kroku donuceni kárným opatřením, zatímco 22 soudců tak učinilo vzdáním se funkce po zahájení kárného řízenî). Pokud pro přehlednost použijeme pro součet soudců odvolaných z funkce soudce kárným soudem a soudců, jež na funkci soudce rezignovali v průběhu kárného řízení, spojení počet soudů „donucených k odložení taláru“, lze konstatovat, že v období před novelou kárná řízení donutila soudce odložit talár v 30 případech z celkových 200 kárných řízení (15\%), zatímco v období po novele to bylo ve 25 př́padech ze 166 kárných ř́zení (zhruba $15 \%$ ).
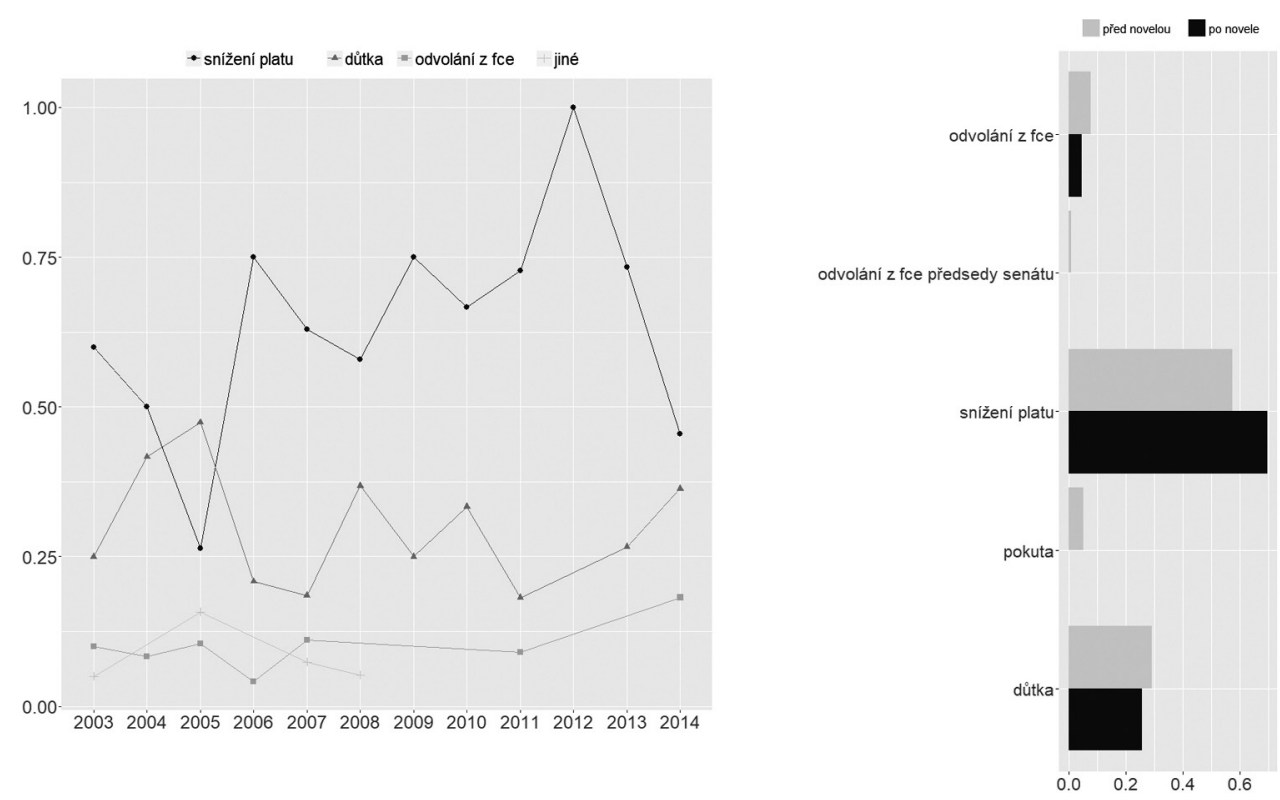

Grafy č. 8 a 9: Podíl řízení, v nichž byla uložena různá kárná opatření, v celkovém počtu řízení zahájených v jednotlivých letech a v období před novelou a po ní

Konečně jako perličku na závěr a záměrně zcela mimo obě skupiny výše definovaných hledisek posuzování dopadů Pospíšilovy novely uvádíme srovnání podílu kárných řízení vedených proti soudkyním na celkovém počtu kárných řízení zahájených v daném roce 
(Graf č. 10). Jde totiž o kritérium, u nějž došlo v období po novele k velmi výrazné změně oproti situaci před novelou. Jak je z grafu patrné, existuje zde tendence spočívající $\mathrm{v}$ poklesu podílu těchto ř́zení v období po novele, ${ }^{62}$ což představuje z kvantitativního hlediska jednu z nejvýznamnějších změn po implementaci Pospíšilovy novely.

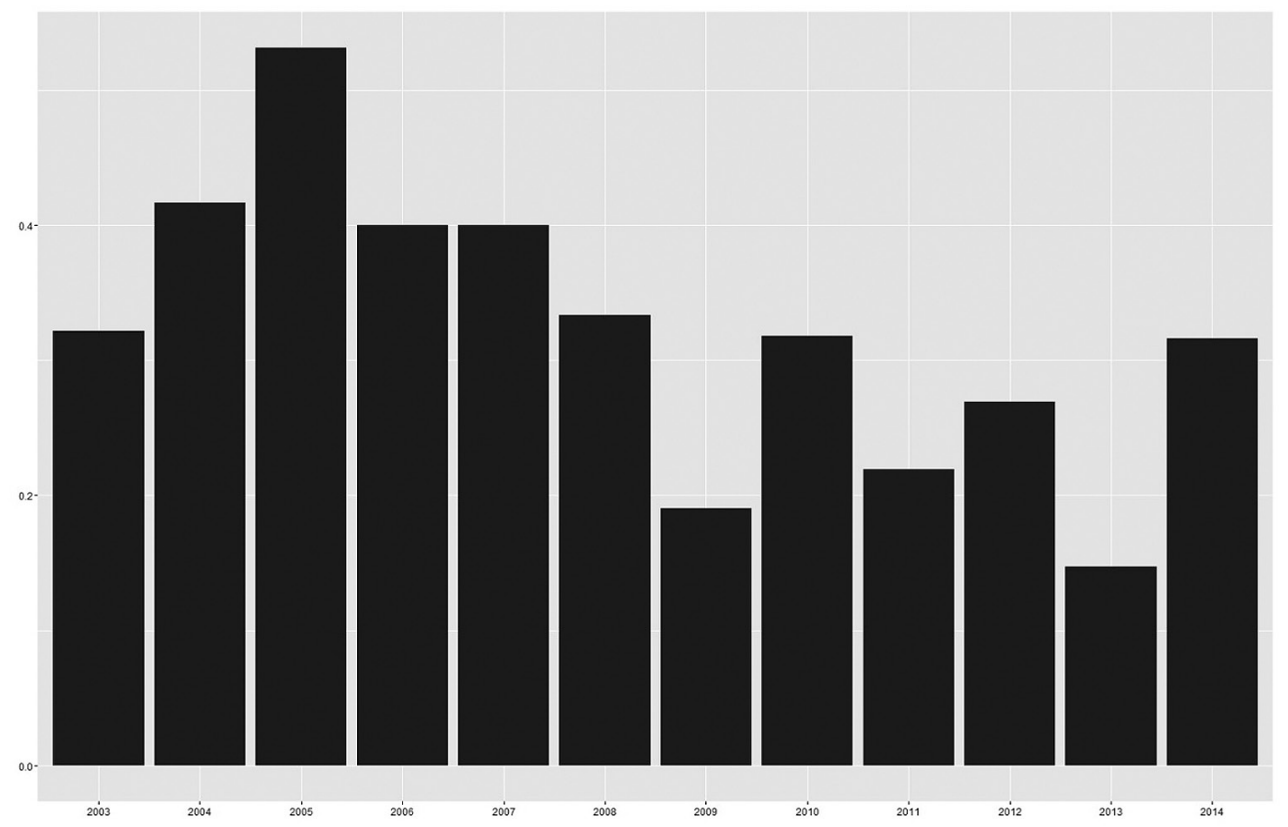

Graf č. 10: Podíl řízení vedených proti soudkyním v celkovém počtu řízení zahájených v jednotlivých letech

\section{Interpretace výsledků}

Po zpracování statistických dat můžeme přejít k jejich interpretaci. Pokud jde o klíčovou otázku položenou v úvodu tohoto článku - přinesla Pospíšilova reforma ve střednědobé perspektivě očekávané zpř́ísnění kárného postihu českých soudců či nikoliv? - lze $\mathrm{v}$ obecné rovině konstatovat, že v drtivé většině sledovaných ukazatelů ke zprrísnění nedošlo. Ve skutečnosti je však odpověd' komplikovanější, nebot' se odvíjí od komparátoru, který považujeme pro posouzení „př́ísnosti“ za klíčový. Můžeme tak odlišit kritéria, u nichž k zpř́ísnění nedošlo, a kritéria, u nichž ke zpř́ísnění možná došlo, nicméně z toliko kvantitativní analýzy to nejsme schopni jednoznačně potvrdit.

Nejprve se zaměříme na kritéria, u nichž k zpřísnění nedošlo. Pokud presumujeme, že se navrhovatelé i soudci chovali obdobně ${ }^{33}$ před Pospíšilovou reformou i po ní, lze

62 Celkově bylo po novele 23 \% kárných řízení vedeno proti ženám, zatímco před novelou to bylo $41 \%$.

63 To je však velmi zásadní předpoklad. 
konstatovat následující. Po Pospíšilově reformě poklesl počet kárných návrhů (z 200 na 168, tj. o $16 \%$ ), nominálně (ze 120 na 66) i percentuálně (z $60 \%$ na $40 \%$ ) poklesl počet kárných návrhů, v nichž bylo uloženo kárné opatření, poklesl i počet soudců zbavených funkce, a to i po započtení rezignací kárně stíhaných soudců (z 30 na 25), a tudíž poklesla i celková úspěšnost kárných navrhovatelů (počítána jako součet řízení, v nichž bylo uloženo kárné opatření, a dobrovolných rezignacî), a to ze 70,5% (141 z 200 řízenî) na $53 \%$ (88 ze 166 ř́izenî).

V této souvislosti je ale nutné upozornit na několik skutečností, jež svědčí proti dovozování dalekosáhlých závěrů z výše uvedených poklesů. Pokud jde o celkový počet zahájených kárných řízení, je nutné zdůraznit, že jejich pokles není nijak závratný a mohl být způsoben celou řadou jiných faktorů, např́klad nejistotou ohledně ústavnosti Pospíšilova modelu kárného soudnictví v prvních letech jeho fungováníi ${ }^{64}$ či rozdílným přístupem jednotlivých ministrů k iniciování kárných ř́zení se soudci. ${ }^{65}$ Nejistota ohledně ústavnosti Pospíšilova modelu by mohla vysvětlovat nízký počet kárných řízení zahájených v letech 2009 a 2010. Rozdílná míra „aktivismu“ ministra spravedlnosti v kárných řízeních pak mohla mít vliv na výrazný nárůst kárných řízení v roce 2011 (viz Graf č. 2), kdy se do funkce ministra spravedlnosti opět dostal Jiří Pospíšil - ten zahájil v roce 2011 výrazně více kárných řízení než kterýkoliv jiný ministr spravedlnosti v jakémkoliv ze sledovaných let 2003-2014. Naopak jeho nástupce Pavel Blažek byl v podávání nových kárných návrhů velmi zdrženlivý a navíc vzal celou řadu kárných žalob podaných svým předchůdcem zpět. Přesný vliv těchto faktorů však naše kvantitativní analýza není schopna odhalit.

Při porovnání počtu soudců „donucených k odložení taláru“ (tj. součtu soudců odvolaných z funkce soudce kárným soudem a soudců, jež na funkci soudce rezignovali v průběhu kárného řízenî) najdeme mezi oběma sledovanými obdobími ještě menší rozdíly. Nominálně sice došlo k poklesu soudců, jimž zanikla funkce soudce v důsledku kárného řízení (a to bud' odvoláním z funkce, nebo z důvodu vzdání se funkce v průběhu kárného řízenî) z 30 na 25 , nicméně pokud tato nominální čísla vztáhneme k počtu zahájených řízení v daném období, tento rozdíl se vytrácí. V obou obdobích totiž kárná řízení vedla k zániku funkce soudce v 15 \% kárných řízení (v období před novelou v 30 případech z 200 řízení, v období po novele v 25 případech ze 166 řízení). Hlavní rozdíl mezi oběma obdobími tak spočívá v poměru odvolaných soudců a soudců, kteří se sami vzdali funkce. Konkrétněji, v období po novele došlo nominálně i percentuálně k více rezignacím (22 vzdání se funkce po novele oproti 21 před novelou), zatímco před novelou kárné

64 Nález Ústavního soudu sp. zn. Pl. ÚS 33/09 byl totiž vynesen až 29. 9. 2010, tj. více než dva roky po účinnosti Pospíšilovy novely.

65 Zatímco po většinu sledovaného období před Pospíšilovou novelou (2003-2008) byli ve funkci jen dva ministři spravedlnosti, Pavel Němec (2004-2006) a Jiří Pospíšil (2006-2009), ve sledovaném období po Pospíšilově novele se na postu ministra spravedlnosti vystřídalo pět lidí (dvakrát Jiř́i Pospíšil, Daniela Kovářová, Pavel Blažek, Marie Benešová a Helena Válková). 
senáty nominálně i percentuálně odvolaly více soudců z funkce (devět odvolaných soudců před novelou oproti třem odvolaným soudcům po novele).

K nejvýraznějšímu poklesu došlo u počtu uložených kárných opatření, a to nominálně i percentuálně. I zde je však nutné ke kvantitativním zjištěním přistupovat obezřetně. $\mathrm{Na}$ nižší počet uložených kárných opatření po Pospíšilově novele mohlo mít totiž vliv hned několik dalších faktorů. V prvé řadě lze zmínit fenomén zpětvzetí kárných žalob, který zásadním zpơsobem deformuje výsledná čísla. Zejména ministr spravedlnosti Pavel Blažek vzal zpět poměrně velké množství kárných žalob (konkrétně pět), týkajících se mnohdy zásadní ústavněprávní otázky slučitelnosti funkce soudce s jinými funkcemi a činnostmi, podaných svým předchůdcem Jiřím Pospíšilem, ${ }^{66}$ a tím znemožnil novým kárným senátům $\mathrm{v}$ těchto věcech meritorně rozhodnout. ${ }^{67}$ Šlo zejména o to, zda soudci mohou zároveň být členy orgánů Fotbalové asociace České republiky. ${ }^{68}$ Krom toho byla řada kárných řízení zahájených po Pospíšilově novele zastavena z důvodu nesplnění subjektivních či objektivních lhůt pro zahájení kárného řízení. Veřejným tajemstvím je též skutečnost, že několik kárných řízení skončilo úplným zproštěním viny kárně stíhaného soudce $z$ důvodu nesprávně formulovaného skutku. Tomu napovídá jak novinový článek Tomáše Němečka zmíněný v úvodu tohoto článku, tak vyjádření předsedkyně jednoho z nových kárných senátů Daniely Zemanové, která opakovaně konstatovala, že „důvodem vysoké neúspěšnosti [kárných žalob po Pospíšilově reformě byla] níkeá kvvalita náurhu na zahájeni kárných rízeni (kárny senát je vázán vymezením skutku, ve keterém je spatrováno kárné provinèní)“, ${ }^{69}$ a že ,ke nejčastéjš̀m vadám patř̀ nedostatečné vymezeni skutku, ve keterém je spatrováno kárné provinèni ${ }^{*}{ }^{70}$ Jinak řečeno, nové kárné senáty nemusí být nutně mírnější v ukládánî kárných sankcí, pouze neměly př́ležitost - vzhledem ke zpětvzetím a nízké kvalitě kárných žalob - o meritu mnoha věcí rozhodnout. Komentář Daniely Zemanové ale lze vykládat i odlišně - že nové kárné senáty začaly klást zvýšené požadavky na kvalitu kárných žalob. ${ }^{71}$

Tím se přesouváme ke kritériím, u nichž možná ke zpř́snění patrně došlo, nicméně toliko z kvantitativní analýzy to nejsme schopni jednoznačně potvrdit. Jedním z takových

66 Srov. též ZEMANOVÁ, 2013, op. cit. (viz pozn. č. 13), s. 7.

67 To nabádá k úvahám, zda je takto nastavená neomezená diskrece kárných navrhovatelů vzít kárnou žalobu zpět namístě.

68 Srov. MÁDL, Luděk. Kvůli fotbalu chystá Pospíšil na soudce kárnou žalobu. AKTUALNE.cz. [online]. 2011, [citováno 21. 11. 2012]. Dostupné z: http://aktualne.centrum.cz/domaci/soudy-a-pravo/clanek. phtml?id=725446. O tom, že $\mathrm{v}$ této problematice nepanuje shoda, svědčí i odborná literatura - srov. zejména KOPA, Martin. Neslučitelnost výkonu funkece soudce s jinými funkcemi a činnostmi. Praha: Linde, 2012; KOUDELKA, Zdeněk. Neslučitelnost funkcí u soudců, státních zástupců a členů vlády. Trestni právo, 2012, roč. 17 , č. 12 , s. $12-18$.

69 Srov. též ZEMANOVÁ, 2013, op. cit. (viz pozn. č. 11), s. 7.

70 Tamtéž, s. 9; Srov. též ZEMANOVÁ, Daniela. Důvody ke změnám existují. Komorní listy, 2015, roč. 7, č. 1, s. 3 .

$71 \mathrm{~K}$ tomu viz níže. 
kritérií je intenzita sankce (kárného opatřenî). Tomuto závěru nasvědčuje nárůst podílu případů s př́ísnější sankcí snížení platu (z 58 na 68 \%) a poklesu podílu případů s mírnější sankcí ve formě důtky (z 29 na 26 \%) v období po Pospíšilově novele. Ještě výrazněji pro tento výklad hovoří zpřísnění v rámci trestu snížení platu spočívající ve zvýšení průměrného platového omezení. Jak bylo zmíněno výše, kárné opatření ve formě snížení platu uložené v řízeních zahájených po novele bylo vůči jednotlivým soudcům v průměru více než dvakrát přísnější (1,53 oproti 0,67 násobku měsíčního platu). Proti tomuto závěru naopak mluví dvě věci. Za prvé, Pospíšilova novela zvýšila horní hranici rozpětí pro kárné opatření snížení platu, a to z $25 \%$ na dobu 6 měsíců před novelou na $30 \%$ na dobu 12 měsícu․ ${ }^{72}$ Nové kárné senáty tak mají k dispozici u této sankce větší rozpětí a je přirozené, že ho začaly využívat. Za druhé, v období po Pospíšilově novele došlo k výraznému snížení počtu prípadů, v nichž kárný senát odvolal soudce $z$ funkce ( $z$ devíti odvolání před novelou na tři odvolání po novele).$^{73}$ Pro potvrzení závěru o zpřísnění intenzity sankce po Pospíšilově reformě bychom tak museli provést podrobnou kvalitativní analýzu, v níž bychom museli srovnávat uložené tresty u obdobných skutků, což jde nad rámec tohoto článku. Tvrzení Tomáše Němečka, že nové kárné senáty zpř́ísnily uložené sankce v obdobných prípadech, ${ }^{74}$ tento článek tedy zcela nevyvrací a na potvrzení či vyvrácení tohoto tvrzení si budeme muset počkat.

Ke zpřísnění po Pospíšilově reformě však patrně došlo ještě v jedné oblasti. Toto zpřísnění ale nelze vyčíst toliko z kvantitativní analýzy provedené v části 2 tohoto článku. Slovy Tomáše Němečka je totiž toto zpřísnění na první pohled „neviditelné“. Spočívá totiž ve zpř́ísnění nároků na kárné žaloby, a to zejména při formulaci skutku, kterého se kárně stíhaný soudce údajně dopustil. Jinak řečeno, to, co by při formulaci skutku před Pospíšilovou novelou u starých kárných senátů prošlo, už po Pospíšilově novele u nových kárných senátů nepostačuje. Toto zpřísnění potvrdili jednomu z autorů článku v rozhovorech zástupci dvou klíčových navrhovatelů v kárných řízeních se soudci, tj. předsedové soudů a pracovníci ministerstva spravedlnosti. ${ }^{75}$ Tento poznatek nás vede k ještě větší opatrnosti při interpretaci dat za roky 2009-2014, nebot' ministerstvo spravedlnosti (a částečně i předsedové soudů) se ze svých chyb mohou poučit a na toto zpřísnění zareagují větším důrazem na kvalitu kárných žalob. Tomuto závěru ostatně odpovídají i výsledky kárných řízení ke konci sledovaného období po Pospíšilově novele,

72 Srov. znění $\int 88(1)(b)$ zákona o soudech a soudcích před Pospíšilovou novelou a po ní.

73 Zde je ale nutné opět zdůraznit, že tento rozdíl může ovlivňovat poměrně vysoký počet dobrovolných rezignací v období po Pospíšilově reformě.

74 Srov. NĚMEČEK, 2012, op. cit. (viz pozn. č. 15), s. 17 in fine.

$75 \mathrm{Na}$ druhé straně je nutné upozornit na skutečnost, že kární navrhovatelé nebudou vždy ochotni přiznat, že důvodem neúspěchu byl špatně sepsaný kárný návrh. Někteří kární navrhovatelé pak v této souvislosti ještě dodávají, že podali kárný návrh proto, aby se vyjasnily kontury toho, co je už kárným proviněním a co ještě nikoliv (např. v souvislosti s př́pustnou mírou svobody projevu soudců či ohledně neslučitelnosti funkce soudce s jinými funkcemi a činnostmi). 
konkrétně za rok 2014, v němž byl podíl kárných řízení, která vyústila v uložení kárného opatření, již srovnatelný s podílem těchto řízeních v letech před novelou.

Ohledně dalších sledovaných kritérií toliko konstatujeme, že vzhledem k počtu soudců okresních soudů a jejich zatížení nepřekvapuje, že se kárná řízení před Pospíšilovou novelou i po ní vedou nejčastěji právě proti nim. Pro znalce českého justičního prostředí není překvapením ani skutečnost, že nejčastějším navrhovatelem v kárných řízeních se soudci jsou v obou obdobích předsedové soudů, na nichž kárně stíhaný soudce působil. Předsedové soudů mají pochopitelně lepší informace o chodu „svého“ soudu a o chování tam působících soudců než předsedové nadřízených soudů. Tato informační asymetrie je ještě větší ve srovnání s ministerstvem spravedlnosti, které má při absenci systému hodnocení soudů a soudců jen omezené informace o každodenním chodu jednotlivých soudů, natož o jednotlivých soudcích. ${ }^{76}$ Tuto informační asymetrii výrazně posiluje i značná fluktuace na postu ministra spravedlnosti, a to zejména vzhledem ke srovnání s délkou mandátu předsedů soudů. ${ }^{77}$ Pokud k tomu přidáme nezralost pracovníků ministerstva spravedlnosti majících na starosti kárná řízení se soudci, ${ }^{78}$ je jasné, proč majî předsedové soudů v této agendě navrch. Drobné výkyvy, zejména v roce 2011, v němž ministerstvo podalo výrazně více kárných žalob než v jiných letech celého sledovaného období (2003-2014), jsou dány spíše osobností aktuálního ministra spravedlnosti (Jiř́ího Pospíšila) a představují toliko výjimku z pravidla.

Zajímavé je, že i soudci samotní jsou přesvědčeni, že kárné návrhy by měli iniciovat primárně předsedové soudů. Např́klad Daniela Zemanová, současná prezidentka Soudcovské unie a toho času předsedkyně jednoho z nových kárných senátů ve věcech soudců při NSS, zastává názor, že ,[v] systému správně nastavených kontrolnich vazęb by mél nejčastěji odhalit provinèni soudcu prèdseda soudu, ke keterému jsou prídèleni “79 Podobný pohled měl i ministr spravedlnosti Pavel Blažek. ${ }^{80}$ Ministr spravedlnosti však může mít na to, zda určité skutky představují kárné provinění, odlišný názor než předsedové soudů, ${ }^{81}$ a to zejména pokud jde o skutky, které údajně představují chování nebo jednání, jímž měl soudce narušovat

76 K tomu srov. blíže KOSAŘ, David. Politics of Judicial Independence and Judicial Accountability in Czechia: Bargaining in the Shadow of the Law between Court Presidents and the Ministry of Justice. European Constitutional Law Review, 2017, roč. 13, č. 96, zejména na s. 99, 102 a 106.

77 Zatímco předsedové soudů byli do roku 2008 jmenovaní na dobu neurčitou a od roku na dobu 7 let (resp. 10 let pro předsedy obou vrcholných obecných soudů), průměrná „životnost“ českého ministra spravedlnosti je kratší než dva roky. Srov. tamtéž, s. 106, pozn. č. 59.

78 Srov. NĚMEČEK, 2012, op. cit. (viz pozn. č. 15).

79 Srov. též ZEMANOVÁ, 2013, op. cit. (viz pozn. č. 11).

80 Srov. např. ČTK. Majitel FC Bohemians podal trestní oznámení na Blažka. AKTUÁLNĚ.cz. [online]. 2012, [citováno 26. 11. 2012]. Dostupné z: http://aktualne.centrum.cz/domaci/soudy-a-pravo/clanek. phtml?id=758719

81 Ostatně český systém kárného řízení nikterak mezi aktivně legitimovanými navrhovateli nerozlišuje (z hlediska toho, kdo má podat kárnou žalobu, resp. zvážit její podání, jako první), a je tedy výhradně na konkrétním ministrovi spravedlnosti, jakou „policy“ bude v této oblasti razit. 
důstojnost soudcovské funkce nebo ohrožovat důvěru v nezávislé, nestranné, odborné a spravedlivé rozhodování soudů. To by mohlo vysvětlovat nárůst kárných řízení pro „rozpor se soudcovskou nezávislostí a etikou“" po Pospíšilově reformě (viz Grafy č. 4 a 5 výše). Mnohem komplikovanější je vysvětlení výrazného poklesu kárných žalob vưči ženám-soudkyním oproti kárným žalobám vůči mužům-soudcům po Pospíšilově reformě (viz Graf č. 10), které představuje z kvantitativního hlediska jednu z nejvýznamnějších změn po implementaci Pospíšilovy novely. Toto „zmírněni““ kárného postihu soudkyň totiž patrně nelze přičítat právě samotné Pospíšilově novele, která je genderově neutrální. Pokles rovněž nelze zdůvodnit zvyšujícím se počtem žen na odvolacích a vrcholných soudech oproti období před Pospíšilovou novelou, protože trend je přesně opačný a na vyšších stupních české soudní soustavy dochází naopak k „defeminizaci“. Stejně tak v období po Pospíšilově novele nedošlo k výraznému navýšení počtu žen na postu předsedy soudu, což by mohlo potenciálně vést k většímu pochopení pro problémy soudkyň ze strany nejčastějšího navrhovatele v kárných řízeních. ${ }^{82}$ Důvody je proto nutné hledat jinde - např́klad v možné genderové předpojatosti (gender bias) ${ }^{83} \mathrm{v}$ zahajování kárných řízení před novelou, které mohlo sloužit jako zastrašení nepohodlných soudkyň či jako donucení nevýkonných soudkyň k většímu počtu „čárek“. Důvody způsobující tento pokles však nelze $z$ našich kvantitativních dat určit. ${ }^{84}$

Na závěr si dovolujeme upozornit na skutečnost, že tato analýza pracuje toliko s výsledky kárných řízení. Je možné, že kární navrhovatelé donutili, resp. přiměli, některé soudce k vzdání se funkce ještě před tím, než proti nim bylo kárné řízení zahájeno. ${ }^{85} \mathrm{~V}$ některých hraničních případech se předsedové soudů mohli naopak rozhodnout udělit dotčenému soudci toliko výtku ${ }^{86}$ či nezahajovat kárné řízení bez dalšího. ${ }^{87}$ Ani jednu z těchto skutečností není schopna tato analýza zachytit. Přesto jsme přesvědčení, že podává z kvantitativního hlediska poměrně věrný obrázek o kárných řízeních se soudci zahájených v letech 2003-2014.

82 Toto je opět téma na samostatný článek. Př́islušná data jsou k dispozici na vyžádání u autorů tohoto článku.

83 Ke komplexnímu zpracování ,genderové předpojatosti“ v českém právu srov. HAVELKOVÁ, Barbara. Gender Equality in Law: Uncovering the Legacies of Czech State Socialism. Oxford: Hart Publishing, 2017.

$84 \mathrm{~K}$ tomu by bylo nezbytné provést hloubkové rozhovory s navrhovateli v kárných řízeních a se soudkyněmi českých obecných soudů (nebo alespoň s jejich reprezentativním vzorkem).

85 Jakkoliv jsou neformální pravomoci předsedů soudů v České republice nepochybně nižší než v Rusku a postsovětském prostoru (k tomu srov. napr. POPOVA, Maria. Politiciz̨ed Justice in Emerging Democracies: A Study of Courts in Russia and Ukraine. Cambridge University Press, Cambridge, 2012, s. 135-145; a KOSAŘ, 2016, op. cit. (viz pozn. č. 48), s. 390-395), jsou stále značné.

86 K tomu srov. ČERNÝ, Petr. Výtka soudci a státnímu zástupci. Prární roz̧bledy, 2014, roč. 23, č. 23-24, s. 835 .

87 Srov. ZEMANOVÁ, 2015, op. cit. (viz pozn. č. 70) - „Za jeden z nejvážnějších považuji selhávání některých kárných žalobců v podobě podávání nekvalitních kárných žalob, př̌padnè v jejich nepodání, prestože to situace vyžaduje“" (důraz doplněn). 


\section{Závěr}

Tento článek porovnal výsledky kárných řízení se soudci zahájených préed Pospíšilovou reformou v letech 2003-2008 s výsledky kárných řízení se soudci zahájených po Pospíšilově reformě v letech 2009-2014, aby zjistil, zda skutečně došlo ke zpřísnění kárného postihu českých soudců. Hlavním závěrem naší kvantitativní studie je, že v rozporu s očekáváním tvůrců Pospíšilovy reformy ke zpř́isnění kárného postihu českých soudců ve střednědobém horizontu v drtivé většině ukazatelů nedošlo. Po implementaci Pospíšilovy reformy totiž poklesl počet kárných návrhů, nominálně i percentuálně poklesl počet kárných řízení, v nichž bylo uloženo kárné opatření, poklesl počet soudců „donucených k odložení taláru“ a poklesla i celková úspěšnost kárných navrhovatelů. K mírnému zpř́ísnění mohlo dojít u intenzity kárných opatření, zejména u sankce snížení platu, nicméně pro ověření tohoto závěru bude nezbytné provést kvalitativní analýzu skutkově podobných případů řešených před Pospíšilovou novelou a po ní. K určitému zpřísnění mohlo dojít rovněž u procesních nároků na kárné žaloby ze strany nových kárných senátů, a to zejména při formulaci skutku, kterého se kárně stíhaný soudce měl dopustit.

$\mathrm{Na}$ to, jak se kární navrhovatelé s tímto kvalitativním posunem vypořádají v dlouhodobém horizontu, si však ještě budeme muset počkat. Stejně tak zůstává nezodpovězenou otázkou, zda proměna institucionálního rámce kárného řízení, kterou prínesla Pospíšilova novela, skutečně vygenerovala jiný typ autority a společenské legitimity kárného řízení ve věcech soudců. ${ }^{88}$ To je totiž v dlouhodobé perspektivě daleko důležitější než změna hmotného kárného práva. ${ }^{89}$

88 Srov. BOBEK, 2011, op. cit. (viz pozn. č. 20).

89 Souladně tamtéž. 